12. Kew O, Morris-Glasgow V, Landaverde M, Burns C, Shaw J, Garib Z, et al. Outbreak of poliomyelitis in Hispaniola associated with circulating type 1 vaccine-derived poliovirus. Science. 2002 Apr 12;296(5566):3569. Epub 2002 Mar 14.

13. Yang CF, Naguib T, Yang SJ, Nasr E, Jorba J, Ahmed N, et al. Circulation of endemic type 2 vaccine-derived poliovirus in Egypt from 1983 to 1993. J Virol. 2003 Aug;77(15):8366-77.

14. World Health Organization. Polio outbreak in Papua New Guinea. Geneva:WHO; 2018 [cited 2019 Oct 7]. Available from https://www. who.int/westernpacific/emergencies/papua-new-guinea-poliovirusoutbreak.

15. World Health Organization. Poliomyelitis. Geneva: WHO;2019 Jul 22 [cited 2019 Oct 7]. Available from https://www.who.int/news-room/ fact-sheets/detail/poliomyelitis

16. Gardner TJ, Diop OM, Jorba J, Chavan S, Ahmed J, Anand A. Surveillance to track progress toward polio eradication - worldwide, 2016-2017. MMWRMorb Mortal Wkly Rep.2018 Apr 13 [cited 2019 Oct 7];67(14):418423. doi: 10.15585/mmwr.mm6714a3

17. Mbaeyi C, Wadood ZM, Moran T, MJourn AF, Stehling-Ariza T, Nikulin J, et al. Strategic response to an outbreak of Circulating Vaccine-Derived Poliovirus Type 2 - Syria, 2017-2018. MMWR Morb Mortal Wkly Rep. 2018 Jun 22;67(24):690-4. doi: 10.15585/mmwr.mm6724a5

18. Patel JC, Diop OM, Gardner T, Chavan S, Jorba J, Wassilak SGF, Ahmed J, Snider CJ. Surveillance to track progress toward polio eradication - worldwide, 2017-2018. MMWR Morb Mortal Wkly Rep. 2019 Apr 5; 68(13):312-8.doi: 10.15585/mmwr.mm6813a4.

19. Global Polio Eradication Initiative. Polio as of 24th April 2019.Geneva: WHO; 2017 [cited 2019 Oct 7]. Available https://reliefweb.int/sites/ reliefweb.int/files/resources/This\%20Week\%20\%E2\%80\%93\%20 GPEI_72.pdf

20. Global Polio Eradication Initiative. Polio as of 26 September 2018. Geneva: WHO; 2018 [cited 2019 Oct 7]. Available from https:// reliefweb.int/sites/reliefweb.int/files/resources/This\%20Week\%20 \%E2\%80\%93\%20GPEI_55.pdf

21. Global Polio Eradication Initiative. Polio this week as of 15 November 2017. Geneva: WHO; 2017 [cited 2019 Oct 7]. Available from https:// reliefweb.int/sites/reliefweb.int/files/resources/This\%20Week\%20 \%E2\%80\%93\%20GPEI_26.pdf

22. Rotary International. End polio now. 2016 review. Bowenrotary.com. 2017 Jan 28[cited 2019 Oct 7]. Available from http://bowenrotary. com/2017/01/rotary-end-polio-now-year-2016-review/
23. Global Polio Eradication Initiative. Polio this week as of 30 September 2015. Geneva: WHO; 2015 [cited 2019 Oct 7]. Available from https:// reliefweb.int/sites/reliefweb.int/files/resources/Polio\%20this\%20 week\%2029092015_0.pdf

24. Jorba J, Diop OM, Iber J, Henderson E, Zhao K, Sutter RW, Wassilak SGF, Burns CC. Update on vaccine-derived polioviruses - worldwide, January 2017-June 2018. MMWR Morb Mortal Wkly Rep. 2018 Oct 26;67(42):1189-94. doi: 10.15585/mmwr.mm6742a5

25. Jorba J, Diop OM, Iber J, Henderson E, Sutter RW, Wassilak SGF, Burns CC.Update on vaccine-derived polioviruses - worldwide, January 2016June 2017. MMWR Morb Mortal Wkly Rep. 2017 Nov 3;66(43):1185-91. doi: $10.15585 / \mathrm{mmwr} . \mathrm{mm} 6643 \mathrm{a} 6$

26. Jorba J, Diop OM, Iber J, Sutter RW, Wassilak SG, Burns CC. Update on vaccine-derived polioviruses - worldwide, January 2015-May 2016. MMWR Morb Mortal Wkly Rep. 2016 Aug 5; 65(30):763-9. doi:10.15585/ mmwr.mm6530a3

27. Diop OM, Burns CC, Sutter RW,Wassilak SG, Kew OM; Centers for Disease Control and Prevention (CDC). Update on vaccine-derived polioviruses - worldwide, January 2014 - March 2015. MMWR Morb Mortal Wkly Rep. 2015 Jun 19;64(23):640-6.

28. John TJ. Vaccine-associated paralytic polio in India. Bull World Health Organ. 2002; 80(11): 917. Epub 2002 Dec 3.

29. Platt LR, Estívariz CF, Sutter RW. Vaccine-associated paralytic poliomyelitis: a review of the epidemiology and estimation of the global burden.J Infect Dis. 2014 Nov 1;210 Suppl 1:S380-9.doi:10.1093/ infdis/jiu184

30. Global Polio Eradication Initiative. Update on vaccine supply. Geneva: WHO; 2017 Apr [cited 2019 Oct 7]. Available from https://www.who. int/immunization/sage/meetings/2017/april/Changblanc_Polio_ Vaccine_Supply_Update_SAGE_April2017.pdf?ua=1

31. United Nations. Population. Geneva: UNO; date unknown [cited 2019 Oct 7]. Available from https://www.un.org/en/sections/issues-depth/ population/

32. John TJ.Two good reasons to drop type 2 virus from oral polio vaccine. Lancet. 2004 Nov 6-12;364(9446):1666.

33. Centers for Disease Control and Prevention. Polio vaccination. 2018 May 4 [cited 2019 Oct 12]. Available from https://www.cdc.gov/ vaccines/vpd/polio/index.html

34. The Immunisation Advisory Centre. Polio. Updated 2017 Apr[cited 2019 Oct 12]. Available from https://www.immune.org.nz/diseases/polio

\title{
Comments on the CRISPR gene-edited babies' case
}

\section{YALI CONG}

\section{Abstract}

Twin girls were born in China in November 2018 to an HIV-positive father and an HIV-negative mother, through in vitro fertilisation

Author: Yali Cong (ethics@bjmu.edu.cn), Professor, Medical Ethics Programme, and Dean, Department of Medical Ethics and Health Law, Peking University Health Science Center, Yifu Teaching Building, 601\#, 38 Xueyuan Road, Haidian District, Beijing, 100191 CHINA(PRC).

To cite: Cong Y. Comments on the CRISPR gene-edited babies' case. Indian J Med Ethics. 2019 Oct-Dec;4(4) NS:297-300. DOI: 10.20529/IJME.2019.039.

Published online on July 30, 2019.

Manuscript Editor: Sunita VS Bandewar

Peer Reviewers: Jing-Bao Nie and an anonymous reviewer

(c) Indian Journal of Medical Ethics 2019 in combination with CRISPR-Cas9 genome editing which altered their CCR5 genes. An investigation found that regulations were broken, and documents were forged. The government needs to address various regulatory defects, improve oversight of research, and implement institutional policies on conflict of interest.

On November 26, 2018, the day before the Second International Summit on Human Genome Editing convened, news of the "CRISPR babies" broke. Twin girls, Lulu and Nana, had been born in China after their parents had received in vitro fertilisation (IVF) treatment, in combination with CRISPRCas9 genome editing which altered their CCR5 genes (1). The principal investigator, He Jiankui, a biophysicist, presented his results to the international media. This news shocked the scientific world. 
The case, which involves an HIV-positive man and an HIVnegative woman, is in contravention of a 2003 Regulation on Assisted Reproduction Technology (Document no. 176) (2) Article 9 of the regulation on health professional staff forbids the manipulation of gametes, zygotes and embryos when used for reproduction.

Prof He edited the CCR5 gene to produce babies that he claimed are not only HIV negative at birth, but also immune to acquiring HIV infection later in life. Established ARTs already permit HIV-positive men to father babies without transmitting the virus to them. And as for future immunity to HIV, it is possible to avoid the risk of HIV exposure. Gene editing provides no special benefit in this case, and the risks are unknown (3).

Gene editing is a powerful new tool for making precise additions, deletions, and alterations to the genome. CRISPR/ Cas9 has made genome editing cheaper, much more precise, efficient, and flexible. Many junior researchers are embracing this technology, but there is a potential risk of "off- target" effects; the harm caused is both unknown and difficult to establish. One does not know the consequences of the premature use of CRISPR-Cas9 for germline editing, and the potential impact on the gene pool (3).

Soon after the story broke, the Southern University of Science and Technology at Shenzhen, where Prof He was employed, announced that his employment had been terminated as of February 1, 2018, and the university had nothing to do with his actions. The Shenzhen Hemei Women and Children's Hospital and other organisations associated with the birth of the "CRISPR babies" also declared that they were not involved with the gene editing (4).

Scientific associations in China, such as the Chinese Society of Stem Cell Research and the Genetics Society of China, condemned Prof He's experiment (5). More than 120 scientists issued a joint declaration condemning He's behaviour (6). The scientific community's concerns focused on the technology's inherent uncertainty and risks to the gene pool. Moreover, it was felt that there was no need to use CRISPR/Cas9 technology in this case, because the couple could have delivered HIV negative babies by using other conventional technologies. Scientists also pointed out that the results of experimental work should not have been disclosed to the public before they had been published in peer-reviewed journals. Many people were uncomfortable that this work had been done in secret during Prof He's leave from the Southern University of Science and Technology (4). This was the first time in China that so many scientists and institutions had voiced opinions on a specific case (6).

The National Natural Science Foundation Commission (NSF) condemned the reported work as "irresponsible acts that violate China's current laws, regulations and scientific ethics" (7) . Incidentally, the NSF funded 42 CRISPR technology-related projects in 2015 valued at 23 million yuan (8).
The PRC's Ministry of Science and Technology and its National Health Commission (NHC) sent an investigative team to Shenzhen. The Ministry of Education issued instructions to research institutions to review their work and report back on the projects they had approved and their mechanisms for oversight of such research (9).

\section{Initial investigation results}

On January 21, 2019, the provincial investigation committee of Guangdong, where the experiment was carried out, reported that Prof He's research team of foreign and domestic researchers had started the project conducting gene editing with IVF as far back as 2016, looking for HIV discordant couples, in which the male was HIV positive. Eight couples were recruited between March 2017 and November 2018. One couple withdrew from the programme. Of the remaining seven couples, two women became pregnant. One gave birth to Lulu and Nana. (10).

The investigation concluded that Prof He's experiments violated scientific integrity and research ethics and broke regulations. It also found that Prof $\mathrm{He}$ had forged the ethics review approval. He had also replaced the men's HIV positive blood samples in the records (10), as the regulation on ARTs bars the use of this technology for people with a sexually transmitted disease.

Personnel and institutions involved with Prof He are now the subject of a criminal investigation. The provincial government announced it would monitor Lulu and Nana, and the other pregnant woman.

The US universities where Prof He studied abroad, Stanford (11) and Rice (12) announced inquiries on their faculty's involvement in the CRISPR baby project. Stanford cleared its researchers; the results of the other investigation are awaited.

\section{Existing guidelines and regulations}

The CRISPR babies research would have been governed by existing regulation on the use of ARTs but there were no national guidelines on the use of gene editing. The US National Academy of Sciences, Engineering and Medicine's document, Human Genome Editing: Science, Ethics, and Governance (13), gives clear guidance on the use of such techniques. Recommendation 5 states:

Clinical trials using heritable genome editing should be permitted only within a robust and effective regulatory framework that encompasses:

- the absence of reasonable alternatives;

- restriction to preventing a serious disease or condition;

- restriction to editing genes that have been convincingly demonstrated to cause or to strongly predispose to that disease or condition;

- restriction to converting such genes to versions that are prevalent in the population and are known to be associated 
with ordinary health with little or no evidence of adverse effects;

- the availability of credible preclinical and/or clinical data on risks and potential health benefits of the procedures;

In response to the scandal, the National Health Commission (NHC) drafted a "Regulation on clinical uses of new biomedical technologies" and called for suggestions from the public on February 26, 2019 (14). Research on high risk biomedical technology, which includes gene-editing, will be reviewed at the provincial level and then submitted to the national health agency for review. Clinical applications of technologies proven safe and effective may be used by local institutions after approval by the provincial government. Violations of the regulations will be punished.

However, the NHC regulation covers only healthcare institutions and will not regulate biology departments in nonmedical universities or biotechnology companies. It was not mere serendipity that the gene-editing case happened at the biology department of Southern University of Science and Technology which is responsible to the Ministry of Education, not the NHC. Research oversight is done in a highly fragmented governance system lacking effective departmental functioning and coordination. For example, universities are usually under the Ministry of Education, and hospitals are usually under the NHC.

\section{Conflict of interest}

Another related issue being discussed in the scientific community is that of conflict of interest.

Prof He was encouraged by the University's policy on translating knowledge into industrial use or for production and patenting. This policy is supported by the Central Government to promote the commercialisation of research and is exemplified in policies such as Promoting the Transformation of Scientific and Technological Achievements. The policy encourages colleges and universities to undertake measures for the transfer of scientific and technological achievements: "If the transformation is successful, [in]obtaining patent, or getting licensing, then not less than 50 percent of the net income from the technology transfer or licensing can be rewarded to individuals who complete this translation..." (15).

These policies are meant to foster innovation as scientists receive financial incentives when innovations are brought to the market. Benefiting from such an effort to encourage faculty to launch startups, Prof He was CEO of Han Hai Gene, a company developing gene sequencing for clinical diagnosis as well as of Direct Genomics Biotechnology, among others (16). There has been no investigation into the possible conflicts of interest, and how this might have influenced his decisions.

Institutions must develop mechanisms of oversight in the translation of research from bench to bedside. Prof He was both an academic researcher with government funding and the CEO of a for-profit gene-sequencing company. This does not necessarily mean that he was guilty of misconduct. It is not known whether the institution where he was employed had developed a COI policy. If it had done so, the institution should have made sure researchers followed it.

\section{Final reflections}

Prof He defended his actions at the press conference where he announced the birth of the CRISPR babies:"I know my research has caused big debate... I am proud of providing hope to the kids to [be] immune from the HIV virus. I will continue to work hard to take responsibility for them for life... if it were my child, I will also take this measure" (17).

Currently, there is consensus that it is not yet time to use germline gene-editing for medical treatment. If it is impossible to predict either the benefits or harms of such techniques, this is sufficient reason for banning their use.

It is reported that the parents in this experiment strongly requested the research team to conduct this procedure on them (17). It is true that many doctors follow unreasonable requests from families, instead of the patient's best interests.

There is another issue which is not discussed widely: whether or not Lulu and Nana's parents had the right to make the decision to remove CCR5 to avoid HIV infection. Parents should, and need to, make decisions for their children. But did the parents act in the best interests of their children? If not, should the government interfere?

Finally, if follow up data of the twin girls provides evidence that Prof He's research was beneficial, how would we view today's condemnation? Which is more acceptable: a good outcome, but breaking the rules? Or following the rules, with a bad result for the babies? Is it tenable to make result-based judgements, or is the rule itself sufficient?

What should the fundamental values be behind such decisions?

Acknowledgements: Dr Yeyang Su for her help in collection of material and discussion.

\section{References}

1. Marchione M. Chinese researcher claims first gene-edited babies. AP NEWS. 2018 Nov 26[cited 2019 Mar 1]. Available from: https://apnews. com/4997bb7aa36c45449b488e19ac83e86d

2. Health Ministry of China. The Revision of the Basic Criteria of Human Assisted Reproductive Technology, the Basic Criteria of Human Sperm Bank-related Technology, the Basic Standard of Sperm Banks, the Ethical Principles of Assisted Reproductive Technology and Human Sperm Bank (Decree No. 176 of 2003). 2003 Aug 11[cited 2019 Mar 1]. Available from: http://www.medste.gd.cn/Html/sciedu/ Class1181/15199620070425102500.html

3. Wang $\mathrm{H}$, Yang $\mathrm{H}$. Gene-edited babies: What went wrong and what could go wrong. PLoS Biol. 2019;17(4): e3000224. https://doi.org/10.1371/ journal.pbio.3000224

4. Shepherd C, Ruwitch J. Scientists, officials in China abhor gene editing that geneticist claims. Reuters.com. 2018 Nov 27 [cited 2019 Mar 1]. Available from: https://www.reuters.com/article/us-health-chinababies-genes-letter-idUSKCN1NW0A7

5. Chinese Society for Stem Cell Research (CSCB) and Genetics Society of China(GSC). Official Statement from CSCB \& GSC: Condeming the reproductive application of gene editing on human germline. 2018 Nov 27[cited 2019 Mar 1]. Available from: http://www.cscb.org.cn/ 
news/20181127/2988.html

6. Yicai.122 scientists collectively declared: strongly condemned first HIV gene editing case. Yicai. 2018 Nov 26 [cited 2019 Mar 1]. Available from: https://www.yicai.com/news/100067069.html

7. Natural Science Foundation of China. Open Letter of the National Natural Science Foundation of China on the "Human Embryo Gene Editing Baby" Event.2018 Nov 29[cited 2019 Mar 1].Available from: http://www.nsfc.gov.cn/publish/portal0/tab442/info74655.htm

8. Fitzpatrick Dimond PF. CRISPR in China. 2016 Dec 27[cited 2019 Mar 1. Available from:] https://www.genengnews.com/insights/crispr-inchina/

9. Xinhua. Research activities of persons halted over gene-edited babies incident. 2018 Nov 29[cited 2019 Mar 1]. Available from: http://www. xinhuanet.com/english/2018-11/29/__137640246.htm

10. Xinhua. Guangdong releases preliminary investigation result of geneedited babies - Xinhua | English.news.cn. 2019 Jan 21 [cited 2019 Mar 1]. Available from: http://www.xinhuanet.com/english/201901/21/c 137762633.htm

11. Krieger LM. Stanford clears its researchers in CRISPR-baby scandal. Mercury News. 2019 Apr 17[cited 2019 May 24].Available from: https:// www.mercurynews.com/2019/04/17/stanford-clears-its-researchersin-crispr-baby-scandal/

12. Joseph A. Rice University opens investigation into researcher who worked on CRISPR baby project. StatNews. 2018 Nov 26[cited 2019 Mar 2]. Available from: https://www.statnews.com/2018/11/26/riceuniversity-opens-investigation-into-researcher-who-worked-on- crisprd-baby-project/

13. National Academies of Sciences Engineering Medicine. Human Genome Editing. Science Ethics and Governance Washington DC; NAP;2017. Available from: https://www.nap.edu/read/24623/chapter/10\#189

14. National Health Commission of the People's Republic of China. Announcement on Public Consultation on the Regulations on the Clinical Application of Biomedical New Technologies (Draft for Comment). 2019 Feb 26 [cited 2019 Mar 1]. Available from: http://www. nhc.gov.cn/wjw/yjzj/201902/0f24ddc242c24212abc42aa8b539584d. shtml

15. Ministry of Science and Technology of the People's Republic of China. Several Opinions of the Ministry of Education of the Ministry of Education on Strengthening the Transfer and Transformation of Scientific and Technological Achievements in Colleges and Universities. Teaching Skills [2016] No. 3. 2016 Aug 17 [2019 Mar 1]. Available from: http://www.most.gov.cn/tztg/201608/t20160817_127255.htm

16. Coleman Z. Chinese 'baby editing' scientist retreats from flagship company. Nikkei Asian Review. 2019 Jul 16 [cited 2019 Jul 20].Available from: https://asia.nikkei.com/Business/Biotechnology/Chinese-babyediting-scientist-retreats-from-flagship-company

17. He Jiankui's live speech and question and answer (showing at the Human Genome Editor International Summit). Cn-healthcare.com . 2018 Nov 29 [cited 2019 Mar 3].

Available from: https://www.cn-healthcare.com/articlewm/20181129/ content-1041657.html.

\section{Starting the conversation: CRISPR's role in India}

\section{FARHAD UDWADIA, SHIVAM SINGH}

\section{Abstract:}

The applications of gene editing technologies such as CRISPR (Clustered Regularly Interspaced Short Palindromic Repeats) have grown significantly in recent years. Several countries have adopted different stances on the regulation of such technology; however, India does not have any legally enforceable regulations in place. There is a need for such a development as India's regulatory, sociocultural, and economic landscape is unique. First, we discuss the uncertainty regarding India's regulatory capacity to enforce ethical standards for CRISPR use. Then, we discuss unique driving forces that could lead to the misuse of CRISPR in India, such as certain sociocultural norms like preferences for fair skin and public demand for sex determination. Given these previous concerns, we posit the question; where on the priority list does CRISPR stand in the context of public health in India?

Author: Farhad Udwadia (corresponding author - farhad.udwadia@ alumni.ubc.ca), MS1 University of British Columbia Faculty of Medicine, Vancouver, British Columbia, CANADA; Neuroethics Canada Office, Koerner Pavilion, 2211 Wesbrook Mall Room S124, Vancouver, BC V6T 2B5, CANADA Shivam Singh (shivam_singh@hms.harvard.edu) Independant Researcher, University Health Network (UHN), Toronto, CANADA

To cite: Udwadia F, Singh S. Starting the conversation: CRISPR's role in India. Indian J Med Ethics. 2019 Oct-Dec;4(4) NS:300-3. DOI: 10.20529/JMME.2019.016

Published online on April 18, 2019.

Manuscript Editor:Vijayaprasad Gopichandran

Peer Reviewers:Two anonymous reviewers

(c) Indian Journal of Medical Ethics 2019

\section{Perspective}

Late in 2018, the world stood by in disbelief as a Chinese scientist reportedly created two genetically engineered human beings using CRISPR (Clustered Regularly Interspaced Short Palindromic Repeats) gene-editing technology (1). This development, which had been merely a challenging possibility not so long ago, has led to the resurgence of a host of ethical questions in the scientific community regarding the use of CRISPR, its off-target effects, access, and regulation (2). On a global front, the technology has been growing faster than our ability to reach any sort of moral consensus on its use and regulation. The successful genetic modification of human embryos, and now, human beings, has fueled apprehensions that this technology could one day be used to design and pick babies with certain designer character traits. Would it be ethical for parents to customise a baby that could run like Usain Bolt and sing like Beyoncé? While experts discredit these specific applications as being unlikely in the near future, the ability to control far less complex and highly heritable traits, such as skin color and gender, are not (3).

Currently, there are no internationally agreed-upon laws or regulations on gene editing, leaving scientific research and application of CRISPR technology to the discretion of individual countries (4). Although some countries, like the United States, the United Kingdom, Canada, and Germany, have strict rules prohibiting genetic modification of the human germ line either experimentally or clinically, other countries 